\title{
Inovasi Pengolahan Keripik Daun Pepaya Guna Meningkatkan Pendapatan Masyarakat
}

\section{Papaya Leaf Chips Processing Innovation In Order to Increase People's Income}

\author{
Tati Mulyati ${ }^{1}$, Tuti Kurnia ${ }^{2}$ \\ 1Program Studi Perbankan Syariah, Fakultas Ekonomi Islam, Universitas Djuanda Bogor, Jl. Tol Ciawi No. 1 \\ Kotak Pos 35 Ciawi, Bogor 16720, e-mail: Tatimulyati2309@gmail.com \\ ${ }^{2}$ Program Studi Ekonomi Syariah, Fakultas Ekonomi Islam, Universitas Djuanda Bogor, Jl. Tol Ciawi No. 1 \\ Kotak Pos 35 Ciawi, Bogor 16720, e-mail: tuti.kurnia@unida.ac.id
}

(Diterima: 25-06-2020; Ditelaah: 15-12-2020; Disetujui: 10-06-2021)

\begin{abstract}
Abstrak
Sumber daya alam yang dihasilkan di Desa Padamulya sangat melimpah tetapi belum sepenuhnya dimanfaatkan oleh masyarakat, sehingga perlu adanya pendampingan kepada masyarakat untuk memanfaatkan potensi sumber daya alam yang ada. Salah satunya dengan memanfaatkan daun pepaya menjadi inovasi produkyang memiliki nilai jual tinggi. Metode pelaksanaan yang dilakukan melalui pelatihan dan pendampingan ekonomi masyarakat dengan membentuk kelompok usaha bersama untuk mengembangkan potensi sumber daya alam yang ada di Desa Padamulya terutama tanaman pepaya. Dalam pengolahan produk daun pepaya ini, penulis membuat inovasi produk keripik daun pepaya. Hasil yang didapatkan adalah terbentuknya kelompok usaha bersama dan pengembangan inovasi produk olahan daun pepaya menjadi lebih kreatif dan inovatif sehingga dapat meningkatkan pendapatan masyarakat.
\end{abstract}

Kata kunci: Inovasi Produk, Keripik Daun Pepaya, Pendapatan Masyarakat

\section{Abstract}

The natural resources produced in Padamulya Village are very abundant but have not been fully utilized by the community, so there is a need for assistance to the community to exploit the potential of existing natural resources. One of them is by utilizing papaya leaves into product innovation that has a high selling value. The method of implementation is carried out through training and community economic assistance by forming joint business groups to develop the potential of natural resources in the village of Padamulya, especially papaya plants. In processing these papaya leaf products, the writer makes an innovation of papaya leaf chips. The results obtained are the formation of joint venture groups and the development of innovations of processed papaya leaf products to be more creative and innovative so as to increase people's income.

Keywords: Community Income, Papaya Leaf Chips, Product Innovation

\section{PENDAHULUAN}

Pengabdian mahasiswa kepada masyarakat dilaksanakan untuk memenuhi salah satu tri dharma perguruan tinggi, yakni pengabdian kepada masyarakat yang bersifat lintas disiplin dan sebagai komponen keilmuan, teknologi dan seni secara aplikatif guna membentuk kehidupan masyarakat, utamanya di pedesaan. Bentuk pengabdian tersebut dilaksanakan dengan cara menerapkan ilmu pengetahuan yang sudah diperoleh di perkuliahan kepada masyarakat. Ilmu pengetahuan yang diterapkan adalah ilmu pengetahuan yang diperlukan oleh masyarakat atau yang dapat menjadi solusi bagi permasalahan yang terjadi kehidupan masyarakat. Hal ini dilakukan sebagai wujud rasa kepedulian dan tanggung jawab mahasiswa untuk memajukan bangsa dan negara di 
masa depan. (Lubis, 2004).

Pendapatan masyarakat dikaitkan dengan tingkat perekonomian, pertanian dan perkebunan serta usaha lainnya yang dilakukan oleh masyarakat dalam menunjang penghasilan keluarga setiap hari. Peningkatan pendapatan masyarakat merupakan suatu kemampuan yang dimiliki oleh masyarakat melalui adanya peningkatan daya beli untuk membiayai kebutuhan sehari-hari baik kebutuhan dasar, kebutuhan sosial maupun kebutuhan lainnya yang terlihat dari peningkatan penghasilan keluarga, pengeluaran keluarga dan perkembangan tabungan keluarga (Femy, 2014). Maka dari itu dengan adanya program ekonomi kreatif yang dilakukan diharapkan mampu merubah pendapatan masyarakat yang ada di Desa Padamulya dengan memanfaatkan sumber daya alam.

Inovasi adalah memulai atau memperkenalkan sesuatu yang baru yang mencakup hasil produk dan proses baru. Adapun tujuan utama proses inovasi adalah memberikan dan menyalurkan nilai pelanggan yang lebih baik (Hartini, 2012). Menurut Irawan (2015), inovasi produk menuju pada pengembangan serta pengenalan produk baru atau produk yang dikembangkan yang berhasil dalam lingkup pemasaran.

Desa padamulya adalah desa yang berada dipegunungan dengan kualitas tanah yang subur sehingga mudah untuk menanam tanaman di Desa tersebut. Seperti tanaman pepaya yang melimpah di Desa Padamulya tetapi masyarakat hanya mengolah daun pepaya sebatas di rebus seperti biasa tanpa adanya inovasi. Jika dapat dikelola dengan baik dan kreatif, daun pepaya tersebut tersebut akan menjadi suatu inovasi baru yang memiliki nilai ekonomi bagi masyarakat.

Sumber Daya Alam yang dihasilkan Desa Padamulya sangat melimpah, akan tetapi sumber daya alam yang dimiliki Desa Padamulya belum sepenuhnya dimanfaatkan oleh masyarakatnya, sehingga perlu adanya pendampingan kepada masyarakat untuk memanfaatkan potensi yang ada. Salah satunya dengan memanfaatkan produk olahan daun pepaya menjadi sebuah makanan inovasi dengan harga nilai jual tinggi. Pemilihan program pemanfaatan olahan daun pepaya ini dilakukan karena potensi daun pepaya yang melimpah akan tetapi tidak dimanfaatkan dengan baik oleh masyarakat.

Tumbuhnya ekonomi kreatif menjadi salah satu konsep untuk pengembangan perekonomian indonesia. yang mana Indonesia bisa mengembangkan model ide dan talenta masyarakat untuk dapat menginovasi dan menciptakan suatau hal. Pola pikir kreatif sangat diperlukan untuk tetap tumbuh berkembang serta bertahan di masa yang akan datang. Pengembangan ekonomi kreatif yang dikeluarkan Kementrian Perdagangan RI (2008) adalah: "Industri kretif yang berasal dari pemanfaatan kreativitas, keterampilan serta bakat individu untuk menciptakan kesejahteraan serta lapangan pekerjaan melalui penciptaan dan pemanfaatan daya kresi dan daya cipta individu tersebut." Berdasarkan uraian di atas maka perumusan masalah adalah ekonomi kreatif sebagai suatu solusi mensejahterakan masyarakat dalam meningkatkan perekonomian.

Pepaya (Carica papaya) adalah tumbuhan yang berasal dari Meksiko bagian selatan dan bagian utara dari Amerika Selatan, dan sudah menyebar luas di seluruh 
daerah tropis untuk diambil buahnya. Daun pepaya merupakan salah satu jenis sayuran yang diolah pada saat masih muda menjadi makanan yang lezat dan bergizi. Disamping itu, daun pepaya dapat menjadi tanaman obat-obatan karena mengandung senyawa alkaloida dan enzim proteolitik, papain, khimopapain dan lisozim, yang berguna pada proses pencernaan dan mempermudah kerja usus. Papain juga berfungsi membantu pengaturan asam amino dan membantu mengeluarkan racun dari dalam tubuh. Daun pepaya juga mengandung vitamin (A, C, E, B1), kalsium, zat besi (Kamaruddin dan Salim, 2003).

Tanaman pepaya merupakan salah satu tanaman yang banyak di tanam oleh masyarakat Indonesia. Tanaman pepaya menjadi tanaman yang dominan ada di halaman rumah. Selama ini pengolahan daun pepaya sebatas rebusan untuk dijadikan lalapan dan tumisan. Untuk variasi pengolahan belum banyak diketahui oleh masyarakat umum khususnya remaja dan ibu-ibu rumah tangga. Sehingga pelaksanaan kegiatan pengabdian ini bertujuan memberikan informasi dan keterampilan baru dalam proses pengolahan daun pepaya kepada remaja dan ibu-ibu rumah tangga.

\section{METODE PELAKSANAAN}

Penulis melakukan pelatihan dan pendampingan ekonomi masyarakat dengan cara memberikan pelatihan pembuatan inovasi produk olahan daun pepaya dan membentuk kelompok usaha bersama yang akan mengembangkan potensi sumber daya alam yang ada disekitar wilayah Desa Padamulya dengan membuat sebuah inovasi produk olahan daun pepaya.

Adapun lokasi yang dijadikan tempat pelaksanaannya adalah Desa Padamulya, Kecamatan Pasirkuda, Kabupaten Cianjur, Provinsi Jawa Barat. Alasan dipilih Desa Padamulya sebagai karena kategori desa tersebut merupakan desa tertinggal, sehingga memerlukan banyak bantuan untuk mengembangkannya, terutama bantuan Sumber Daya Manusia (SDM) untuk mengembangkan potensi yang ada di Desa tersebut.

Kajian teori tersebut untuk mendukung penyusunan program kerja di bidang ekonomi untuk mengatasi permasalah-permasalah ekonomi di Kampung Mekarjaya Desa Padamulya. Berikut program kerja yang dilaksanakan terdapat pada Tabel 1.

\section{Tabel 1 Program Kerja yang Dilaksanakan}

\begin{tabular}{cl}
\hline Program Kerja & \multicolumn{2}{c}{ Uraian Program } \\
\hline & Pelatihan pembuatan inovasi produk olahan \\
daun pepaya memiliki nilai jual tinggi dan \\
Pelatihan Pembuatan Produk & mampu membantu memanfaatkan potensi \\
Olahan Daun Pepaya & sumber daya alam yang ada sekaligus \\
& meningkatkan pendapatan masyarakat.
\end{tabular}




\section{HASIL \& PEMBAHASAN}

Hasil dari pengabdian masyarakat ini adalah terbentuknya inovasi produk dan kelompok usaha bersama dengan nama KUB Mekarjaya. KUB Mekarjaya sendiri terbagi menjadi 6 kelompok. Selain terbentuknya Kelompok Usaha Bersama (KUB) Mekarjaya, hasil dari kegiatan ini dengan diadakannya pembekalan cara penjualan produk tersebut di Online Shop. Produk yang dihasilkan dari kegiatan Program ini adalah pemanfaatan daun pepaya yang diolah menjadi inovasi produk keripik daun pepaya. Pembuatan produk tersebut bertujuan untuk meningkatkan nilai jual daun pepaya dan mempunyai nilai ekonomi yang tinggi untuk masyarakat Desa Padamulya.

Metode pelaksanaan yang dilakukan penulis berupa program pelatihan dan pendampingan ekonomi masyarakat dengan cara membentuk kelompok usaha bersama yang akan mengembangkan potensi sumber daya alam yang ada di sekitar wilayah Desa Padamulya terutama daun pepaya. Program inovasi produk keripik daun pepaya yang memanfaatkan tanaman pepaya yang melimpah di Desa tersebut sangat efektif dijadikan sebagai makanan ringan bahkan makanan oleh-oleh khas daerah Desa Padamulya. Dengan adanya pelaksanaan kegiatan pengabdian kepada masyarakat ini bermunculan ide untuk mengembangkan kelompok usaha bersama dengan memanfaatkan banyaknya tanaman pepaya menjadi inovasi produk daun pepaya dengan pengemasan yang menarik sehingga dapat menarik perhatian konsumen dan dapat menaikan tingkat pendapatan masyarakat Kampung Mekarjaya Desa Padamulya.

Pembuatan inovasi produk olahan daun pepaya melalui pelatihan masyarakat Kampung Mekarjaya Desa Padmulya yang dilaksanakan berdasarkan survei bahwa masyarakat Kampung Mekarjaya Rt 02 Rw 08 menanam tanaman pepaya di setiap halaman rumah. Adapun perubahan setelah pelaksanaan yang diharapkan adalah sebagai berikut :

Tabel 2 Perubahan yang Diharapkan

\begin{tabular}{|c|c|c|c|}
\hline No & Keterangan & Sebelum Pelaksanaan & Setelah Pelaksanaan \\
\hline 1 & Daun pepaya & $\begin{array}{l}\text { Diolah hanya sebagai } \\
\text { rebusan untuk dijadikan } \\
\text { lalapan dan tumisan. }\end{array}$ & $\begin{array}{l}\text { Diolah menjadi inovasi } \\
\text { produk makanan ringan } \\
\text { keripik daun pepaya dan } \\
\text { memiliki nilai jual } \\
\text { ekonomis. }\end{array}$ \\
\hline 2 & $\begin{array}{l}\text { Keterampilan mengolah } \\
\text { daun pepaya menjadi } \\
\text { sebuah produk. }\end{array}$ & $\begin{array}{l}\text { Belum } \\
\text { keterampilan. }\end{array}$ & $\begin{array}{l}\text { Daun pepaya diolah } \\
\text { menjadi produk } \\
\text { makanan ringan dan } \\
\text { memiliki nilai jual yang } \\
\text { lebih tinggi. }\end{array}$ \\
\hline 3 & Pemasaran daun pepaya & $\begin{array}{l}\text { Sebatas dijual dalam } \\
\text { bentuk daun pepaya biasa } \\
\text { pada umumnya }\end{array}$ & $\begin{array}{l}\text { Pemasarannya lebih } \\
\text { luas yaitu toko oleh- } \\
\text { oleh, supermarket dan }\end{array}$ \\
\hline
\end{tabular}




online shop dalam
bentuk inovasi produk
keripik daun pepaya
yang memiliki nilai
ekonomis.

Berikut tahap pelaksanaan program pelatihan dan pendampingan pembuatan inovasi produk olahan daun pepaya.

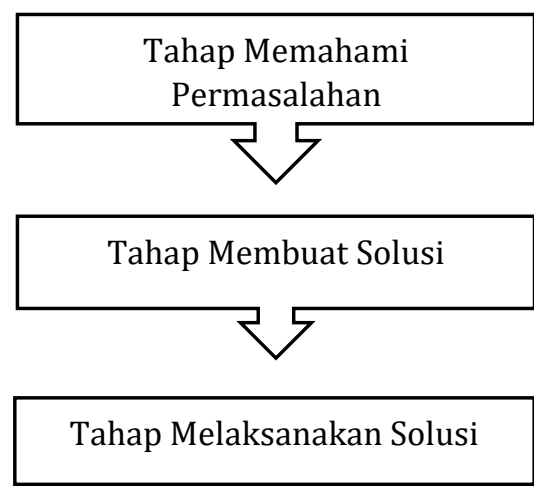

Gambar 1.Tahap Pelaksanaan Penelitian

\section{1) Tahap Memahami Permasalahan}

Dalam tahap ini penulis memahami permasalahan di Kampung Mekarjaya Desa Padamulya dengan cara melakukan survei kepada masyarakat dalam rangka mengidentifikasi masalah yang ada. masalah yang ditemukan di masyarakat Kampung Mekarjaya Desa Padamulya adalah banyaknya tanaman pepaya atau potensi sumber daya alam yang tidak dimanfaatkan dengan baik, dan belum ada inovasi baru terhadap potensi sumber daya alam tersebut. Selain itu tidak adanya pendampingan kegiatan ekonomi kepada masyarakat terutama pendampingan kelompok usaha bersama.

\section{2) Tahap Membuat Solusi}

Dalam tahap membuat solusi terbagi menjadi beberapa tahap diantaranya :

\section{a. Survei Sumber Daya Alam (SDA)}

Survei lokasi dilakukan di wilayah Kampung Mekarjaya Rt 01 Rw 08 Desa Padamulya. Pelaksanaan survei dilakukan dengan cara melihat potensi tanaman pepaya yang melimpah dan berada disetiap halaman rumah, kemudian mencari tahu kebiasaan masyarakat dalam memanfaatkan daun pepaya tersebut. Hasil dari survei yang sudah dilakukan ialah, banyaknya tanaman pepaya yang ada dikampung tersebut, namun tidak di manfaatkan dengan baik. Masyarakat memanfaatkan daun pepaya hanya dengan direbus atau dijadikan tumisan namun tidak untuk dijual atau diolah menjadi produk yang mempunyai nilai jual tinggi. 


\section{b. Percobaan Pembuatan Inovasi Produk}

Berdasarkan hasil survei yang dilakukan oleh tim pelaksana, banyak tanaman pepaya yang ada diwilayah Desa Padamulya tersebut. Untuk meminimalisir terjadinya kegagalan dalam pembuatan inovasi produk maka penulis melakukan percobaan inovasi produk daun pepaya tersebut. Percobaan pembuatan keripik daun pepaya ini dilakukan satu kali dan menemukan hasil yang sempurna dan sesuai dengan apa yang diinginkan.

c. Membuat Desain Logo dan Kemasan

Pembuatan desain kemasan dibuat dengan semenarik mungkin agar menarik perhatian konsumen. Langkah pembuatan desain produk meliputi:
a. Penulis menggunakan aplikasi picsart dan photo shoot untuk membuat desain logo produk
b. Menentukan format penulisan, font, size dan warna.
c. Mencantumkan logo kelompok dan logo fakultas.
d. Mencantumkan komposisi keripik daun pepaya.

\section{d. Pembelian Bahan Kebutuhan Produk}

Penulis menyediakan kemasan produk yang sudah dibuat kemudian menyiapkan bahan-bahan untuk pembuatan keripik daun pepaya antara lain daun pepaya, tepung beras, tepung kanji, bawang putih, penyedap rasa, telur, kerumbar, merica, kemiri, air dan minyak goreng.

\section{e. Sosialisasi Kepada Masyarakat}

Setelah melakukan survei lokasi, percobaan pembuatan inovasi produk dan membuat desain kemasan, selanjutnya penulis melakukan sosialisasi kepada masyarakat mengenai inovasi produk. dengan memperkenalkan inovasi produk yang akan dibuat serta proses pembuatannya dan pembentukan usaha bersama.

\section{3) Tahap Melaksanakan Solusi}

Dalam melaksanakan solusi dilakukan pelatihan inovasi produk pembuatan keripik daun pepaya yang dilaksanakan pada hari Selasa tanggal 20 Agustus 2019 dan hari Minggu 25 Agustus 2019. Pelatihan produksi produk ini dihadiri oleh remaja dan ibu-ibu Kampung Mekarjaya Rt 02 Rw 08.

Produksi pembuatan keripik daun pepaya dilakukan dengan beberapa tahap seperti proses pengrebusan, proses pencucian, proses pemotongan, proses penggorengan hingga proses pengemasan. Berikut proses pembuatan keripik daun pepaya :

1) Tahap pertama, proses pengrebusan daun pepaya. Daun pepaya di rebus dengan daun harendong agar rasa pahit pada daun pepaya hilang. Selanjutnya, dilakukan pencucian daun pepaya untuk menghilangkan kotoran yang ada di daun pepaya, lalu tiriskan daun pepaya tersebut.

2) Tahap kedua, proses pemotongan daun pepaya. Setelah daun pepaya bersih, selanjutnya daun pepaya dipotong menjadi kecil menggunakan gunting atau pisau. 
3) Tahap ketiga, proses penggorengan dan pengolahan daun pepaya. Siapkan minyak goreng secukupnya, setelah daun pepaya dipotong menjadi kecil, selanjutnya siapkan adonan yang harus dihaluskan seperti bawang putih, ketumbar, kemiri dan merica. Siapkan baskom lalu masukan tepung beras, tepung kanji, kuning telur, penyedap rasa dan bumbu yang telah dihaluskan tambahkan air secukupnya lalu aduk hingga rata. Kemudian masukan daun pepaya yang sudah di potong menjadi kecil kedalam adonan dan masukan kedalam penggorengan satu persatu kedalam minyak yang sudah panas dan tunggu hingga berwarna keemasan lalu angkat dan tiriskan, agar minyak yang terdapat di keripik tersebut berkurang.

4) Tahap kelima, proses pengemasan. Tahap terakhir yang dilakukan dalam pembuatan keripik daun pepaya yaitu melakukan proses pengemasan. Keripik daun pepaya yang sudah ditiriskan dimasukan kedalam kemasan plastik yang sudah disiapkan dan diberi stiker kemasan.

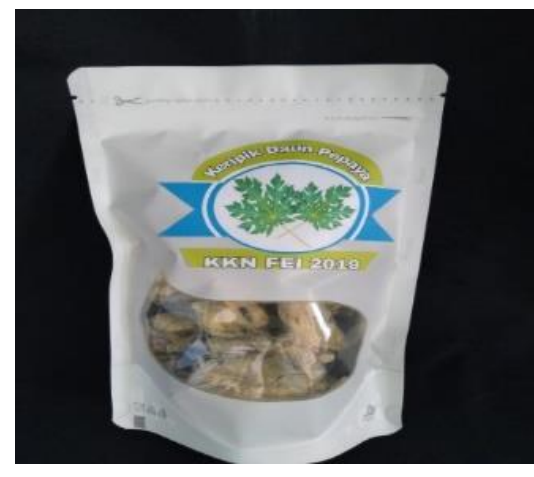

Gambar 2. Produk Keripik Daun Pepaya

\section{KESIMPULAN DAN IMLPIKASI}

Pengabdian kepada masyarakat dilakukan di Desa Padamulya dalam rangka meningkatkan potensi sumber daya alam terutama dengan memanfaatkan daun pepaya menjadi inovasi produk keripik daun pepaya. Inovasi ini memiliki nilai ekonomi yang tinggi sehingga dapat meningkatkan pendapatan masyarakat. Hasil dari pelatihan inovasi produk menghasilkan enam kelompok usaha bersama salah satunya berupa produk keripik daun pepaya dan dengan adanya kegiatan pelatihan inovasi produk olahan daun pepaya ini dapat menjadikan makanan oleh-oleh khas Desa Padamulya.

Setelah dilaksanakannya pengabdian kepada masyarakat di Desa Padamulya Kabupaten Cianjur, masyarakat menyadari dan memahami dengan memanfaatkan sumber daya alam yang ada yaitu daun pepaya dapat dijadikan inovasi produk keripik daun pepaya yang memiliki nilai ekonomi yang tinggi sehingga mampu meningkatkan pendapatan masyarakat. 


\section{DAFTAR PUSTAKA}

Aldy Purnomo, Rochmat. 2016. Ekonomi Kreatif Pilar Pembangunan Indonesia. Surakarta: Ziyad Visi Media.

Afiff, Faisal. 2012. Pilar-Pilar Ekonomi Kreatif. Artikel. Universitas Bina Nusantara: Jakarta

Djayadiningrat, Ainda, Fauziyyah. 2017. Peran Inovasi Produk Memediasi Orientasi Kewirausahaan Terhadap Kinerja Pemasaran IMK Sektor Industri Makanan Kota Denpasar. E-Jurnal Manajemen Unud. Vol 6 No 9.

Femy. 2014. Peningkatan Pendapatan Masyarakat Melalui Program Pemberdayaan Di Desa Lolah II Kecamatan Tombariri Kabupaten Minahasa. Jurnal LPPM Bidang EkoSosBudKum. Vol 1 No 1.

Hartini, Sri. 2012. Peran Inovasi Pengembangan Kualitas Produk dan Kinerja Bisnis. Jurnal Manajemen dan Kewirausahaan. Vil 14 No 1.

Irawan, B, R. 2015. Dampak Inovasi Produk Terhadap Kinerja Pemasaran. Jurnal AROGA. Vol 3 No 1.

Kurniawati, Dwi, Pratiwi. 2013. Pemberdayaan Masyarakat Di Bidang Ekonomi. Jurnal Administrasi publik. Vol 1 No 4.

Kusmanto, Y. T. (2014). Pengembangan Ekonomi Islam Berbasis Kependudukan di Perdesaan. Jurnal Ilmu Dakwah, Vol. 34 No. 2, Pp. 232.

Tawas, H, N. 2014. Pengaruh Orientasi Kewirausahaan, Inovasi Produk, dan Keunggulan Bersaing Terhadap Kinerja Pemasaran Usaha Nasi Kuning di Kota Manado. Jurnal EMBA.Vol 2 No 3. 